\title{
Article \\ Adoption of Big Data Analytics and Its Impact on Organizational Performance in Higher Education Mediated by Knowledge Management
}

\author{
Giulio Franz Marchena Sekli *(D) and Iván De La Vega (D) \\ CENTRUM Catolica Graduate Business School, Pontificia Universidad Catolica del Peru, Lima 15000, Peru; \\ idelavega@pucp.edu.pe \\ * Correspondence: a20106806@pucp.pe
}

Citation: Marchena Sekli, G.F.; De La Vega, I. Adoption of Big Data Analytics and Its Impact on Organizational Performance in Higher Education Mediated by Knowledge Management. J. Open Innov. Technol. Mark. Complex. 2021, 7 221. https://doi.org/10.3390/ joitmc7040221

Received: 17 September 2021 Accepted: 21 October 2021

Published: 2 November 2021

Publisher's Note: MDPI stays neutral with regard to jurisdictional claims in published maps and institutional affiliations.

Copyright: (c) 2021 by the authors. Licensee MDPI, Basel, Switzerland. This article is an open access article distributed under the terms and conditions of the Creative Commons Attribution (CC BY) license (https:/ / creativecommons.org/licenses/by/ $4.0 /)$.

\begin{abstract}
Due to SARS-CoV-2 pandemic, higher education institutions are challenged to continue providing quality teaching, consulting, and research production through virtual education environments. In this context, a large volume of data is being generated, and technologies such as big data analytics are needed to create opportunities for open innovation by obtaining valuable knowledge. The purpose of this paper is to investigate the factors that influence the adoption of big data analytics and evaluate the relationship it has with performance and knowledge management, taking into consideration that this technology is in its initial stages and that previous research has provided varied results depending on the sector in focus. To address these challenges, a theoretical framework is developed to empirically test the relationship of these variables; 265 members of universities in Latin America were surveyed, and structural equation modeling is used. The findings identify compatibility, an adequate organizational data environment, and external support as factors required to adopt big data analytics, and their positive relationship is tested with knowledge management processes and organizational performance. This study provides practical guidance for decisionmakers involved in or in charge of defining the implementation strategy of big data analytics in higher education institutions.
\end{abstract}

Keywords: big data analytics; knowledge management processes; organizational performance; higher education institutions; dynamics capabilities

\section{Introduction}

The current organizational environment is characterized by rapid changes that make it difficult to meet customers' needs. This situation has been intensified by the SARSCoV-2 pandemic and its variants [1], forcing many companies to transform by adopting technologies and strategies to achieve a competitive advantage that prepares them for the new normal [2-4] with the increasing use of digital environments [5,6]. Under this scenario, the ways in which organizations have adapted to the pandemic have generated an extraordinary amount of data that can be used to create knowledge for higher decisionmaking [7-9]. Knowledge is a valuable resource that contributes to better organizational performance, and it must be managed through processes of acquisition, dissemination, and use that require a precise understanding $[10,11]$ in an environment in which a great amount of information is generated in digital channels [12]. Since the start of the new millennium, knowledge management (KM) processes have been affected by the arrival of the fourth industrial revolution, which has brought new forms of learning and knowledge creation, such as big data analytics (BDA) $[11,13,14]$.

BDA is defined as the processing of a large amount of data using mathematical and statistical techniques that allow organizations to discover patterns, identify anomalies, and generate valuable knowledge [15]. BDA is applied in different sectors, including that of education [16]; higher education institutions (HEIs) can collect a large amount of 
information during the teaching process [16] and use BDA to address the challenges of increasing global competition $[15,17]$. Under the global context of accelerated change, BDA can provide HEIs with a competitive advantage and a source of open innovation when they manage to gather information from online learning experiences and other sources such as social networks. BDA allows them to model individual students' learning behaviors as well as those of the market [18]. In this way, BDA could enable academic and learning analytics to improve the quality of education or optimize the curriculum, or to identify students with a high probability of dropping out of a course before its completion and take personalized counseling actions [19-21], among other benefits of data-driven decision making [14-17]. In addition to BDA, KM processes become paramount when the goal of an organization is to react skillfully and strategically [22], but this requires generating dynamic capabilities. Moreover, in the case of HEIs, the knowledge obtained in this new educational modality must be managed to create value, provide key services, and plan for the next normality $[2,12]$.

Despite the importance of the application of BDA, as it is a disruptive technology in early stages of adoption, there are gaps in its implementation due to a lack of understanding of the necessary elements for its success and the decrease in the levels of risks and associated costs [23-26]. Further, an exhaustive literature search in major scientific databases such as Web of Science (WoS) and Scopus indicates that little research has considered the factors that influence the adoption of BDA $[27,28]$ and even fewer studies have adopted a holistic view to validate the organizational context $[25,29]$. Under the technology, organization, and environment (TOE) theoretical framework, which has been widely used to measure BDA adoption [30], previous studies came to varied conclusions [31-33]. In HEIs, the study of factors influencing BDA adoption becomes more relevant; a study on BDA technology adoption in educational sectors found that they use only $3 \%$ of analytical data, and more empirical findings of its application are needed [24].

However, although research has been conducted on BDA in various sectors, it has rarely focused on HEIs and most has been conducted in developing countries where the level of adoption is not clear [18,30,33-36], considering that the factors that impact adoption vary according to the characteristics of each industry $[9,23]$. Previous research presents contradictory results regarding the impact of BDA on organizational performance; while studies in several industries have recognized its positive impact [18,37-39], others still find its influence on organizational performance diffuse [11,40,41]. Despite the growing number of studies analyzing BDA and its impact on performance, little attention has been paid within HEIs [18,42]. Moreover, the lack of a general understanding on how BDA can optimize operations and strategy in this sector generates resistance with regards to investing in its application [37].

Regarding the impact of KM processes on organizational performance, despite its importance for HEIs given the complexity and massive existence of knowledge [43], few empirical studies have attempted to clarify the relationship between KM processes and organizational performance [44], specifically in HEIs [45,46]. Although studies have been conducted, they cannot be generalized due to the different cultures and structures they examined [45]. Likewise, regarding the relationship between BDA and KM processes, as well as the mediating effect of KM processes between BDA and organizational performance, while some research provides empirical evidence for their relationship [47-49], other research presents more critical views [50-52], and little attention has been paid to their application within HEIs $[18,42]$. Previous studies found that some of the value derived from investments in BDA information systems has yielded mixed results, giving rise to the productivity paradox of information technology [53]. In fact, some studies argue that BDA and KM processes do not necessarily lead to better organizational performance or that KM processes have a partial mediating effect between BDA and organizational performance [39]. Meanwhile, other studies find positive associations between them [53] and some have recommended verifying the mediating role that KM processes can play in relation to performance and innovations [54], in this case, BDA. 
To address these issues, this study contributes to the existing literature in four ways. First, it identifies the factors that influence the adoption of BDA in HEIs, a sector that has lagged behind other industries in adopting this technology, making it unclear whether they are ready to adopt BDA $[25,30,36,55]$. Second, it examines the potential impact of BDA on organizational performance in understudied sectors such as HEIs $[39,53]$. Third, it evaluates the mediating effect of KM processes on the relationship between BDA and organizational performance, which allows the knowledge acquired to be shared and used to generate value in the organization $[39,56,57]$. Fourth, although previous studies on BDA have been conducted in developing countries, it is still an under-examined area [18,46] and few studies exist on HEIs [30,34]. Thus, this study contributes to the literature by applying these concepts in developing countries in Latin America. From a practical perspective, this study provides guidance to HEI teams and decision-makers regarding factors to consider in the successful implementation of BDA and the KM processes required to positively impact performance.

\subsection{Conceptual Framework and Hypothesis Development}

\subsubsection{Adoption of BDA}

O'Leary [58] defines big data as a large amount of structured and unstructured data that, due to its complexities, cannot be managed using traditional methods. Although there is no unanimous agreement on the characteristics of big data, the term is coined mainly to refer to data that is characterized by being generated at high speed and in large volume, coming from a wide variety of sources that provide veracity about the information and provide value for decision making $[18,59,60]$; hence, the definition of the $5 \mathrm{Vs}$ of big data. BDA has been referred to as the ability to process and analyze the results of big data [60] and provide descriptive, predictive, and prescriptive results [61]. Several theories are proposed to describe the factors that influence the adoption of technology such as BDA; among these, the TOE framework developed by Tornatzky and Fleischer [62] stands out. Previous literature uses the TOE framework to analyze forms of innovation such as e-business or cloud computing $[63,64]$, and other studies use it in the context of BDA in sectors other than HEIs $[55,65,66]$, making it an appropriate framework for recognizing the technological, organizational, and environmental factors that influence organizational performance $[24,25,29,36]$.

Technological factors refer to the endogenous and exogenous elements of a technology that are critical to its adoption [33], organizational factors refer to structural aspects of the organization that can influence technological adoption [27], and environmental factors are external elements that can influence an organization's adoption of a technology [67]. Although BDA is recognized as a technology that can provide competitive advantages, its adoption rate has not grown as fast as expected [33], and many studies have focused on the technical perspective $[65,68]$. Despite the importance of implementing and using big data to secure competitive advantages and improve business performance, existing studies on the factors influencing its adoption have been insufficient [23,29].

In this context, the current study examines the technological factors of complexity and compatibility consistent with previous studies that consider these factors relevant in the adoption of innovation $[27,33,69]$. Complexity is the degree to which innovation is perceived as being relatively difficult to understand and use [27]. Recent literature recognizes the complex task of implementing BDA in organizations due to aspects such as data security and privacy, architecture availability, and technology diversity [70], which are aspects that negatively influence its adoption [29]. Therefore, the following hypothesis is proposed:

Hypothesis 1 (H1). Complexity negatively influences the adoption of BDA.

Compatibility refers to the degree to which a new system is consistent with those that currently exist in the organization [71]. BDA adoption requires that a system is well- 
matched to current organizational IT resources and requirements [28]; innovations that match available technologies and current procedures are more readily accepted [29,72]. Previous studies have identified compatibility as a significant determinant for BDA adoption [73]; therefore, the following hypothesis is proposed:

Hypothesis 2 (H2). Compatibility positively influences the adoption of BDA.

Top management support, organizational data environment, and organizational readiness are considered as organizational factors [29,33,74]. Top management support is a fundamental factor in creating a supportive environment and providing adequate resources to adopt a new technology [27]; in the case of BDA, it is a critical factor due to the need for adequate and coordinated resources for the required data integration and architecture. Therefore, the following hypothesis is proposed:

Hypothesis 3 (H3). Top management support positively influences BDA adoption.

The organizational data environment refers to the ability to access previously unavailable information, as well as the ability to reduce errors when accessing information [75]. $\mathrm{BDA}$ is characterized by the use of data from diverse sources and thus has diverse formats; the correct cleaning and transformation of the information will provide a high-quality data environment [27]. Therefore, the following hypothesis is proposed:

Hypothesis 4 (H4). A suitable organizational data environment positively influences the adoption of $B D A$.

Organizational readiness refers to the ability of organizations to manage and invest in the adoption of new technology, including the capacity and technical expertise required by the IT area [33]; in the case of BDA, researchers agree that this is a fundamental prerequisite for its proper adoption [29]. Therefore, the following hypothesis is proposed:

Hypothesis 5 (H5). Organizational readiness positively influences the adoption of BDA.

Finally, regarding environmental factors, competitive pressure and external support are considered $[66,76]$. Competitive pressure increases as competition seeks advantages through innovation [27]; in that sense, the adoption of BDA can benefit organizations by presenting a better understanding of the market and generating more accurate data-driven decisions. Therefore, the following hypothesis is proposed:

Hypothesis 6 (H6). Competitive pressure positively influences the adoption of BDA.

External support, in contrast, refers to the support that can be provided by suppliers for the adoption of a technology [29]; in the case of BDA, receiving support from specialized suppliers allows for the development of the necessary capabilities for its proper implementation [29], although the literature states that the support provided by suppliers is mostly limited to faculty level only and not at the level of HEI as a whole yet [36] Therefore, the following hypothesis is proposed:

Hypothesis 7 (H7). External support positively influences the adoption of $B D A$.

While there is an extensive body of literature on BDA adoption, few offer organizationallevel perspectives $[23,25]$ and adoption factors may vary by industry [55]; in particular, the education sector still lags behind other industries in BDA adoption and it is unclear whether it is prepared for the implementation of the technology $[24,36]$. 


\subsubsection{Relationship between BDA and Organizational Performance in HEIs}

BDA and its application in order to achieve higher organizational performance is grounded in resource-based theory [77], which states that a firm's performance depends on the extent to which it simultaneously possesses valuable, rare, imperfectly imitable, and appropriately organized resources $[78,79]$. In line with the resource-based theory, $\mathrm{BDA}$ is considered a resource that provides competitive advantages by being valuable and possessing key capabilities that generate superior organizational performance [80]. Interrelationships between different BDA capabilities are essential, as they lead to better performances and a model that is difficult for competitors to imitate [81]. It is worth mentioning that other researchers have approached BDA from a resource-based perspective $[18,38,39,60,82]$.

Previous studies found that an organization's ability to collect, prepare, and analyze information has a positive effect on performance indicators such as profitability or return on investment [53] and can therefore provide a competitive advantage if BDA capabilities that are difficult to imitate are developed [83]. In the case of HEIs, [18] BDA could enable informed decision making based on in-depth analysis of data to improve business' performance and, in this process, turn HEIs into data-driven organizations with impacts on value creation [37]. HEIs such as Purdue University, Nottingham Trent, and Cambridge have been using BDA to improve students' experience and reduce dropout rates, resulting in improvements in their performance and reputation [18]. In India, HEIs understand that the ability to analyze and utilize large data sets will be a major source of competitive advantage in the twenty-first century [37]. Previous studies identified various applications of analytics in learning and teaching in HEIs [70,84]; among the various applications, by collecting data such as students' profiles, their level of participation, and relevant historical data from previous semesters, it is possible to forecast students' performance and make pedagogical adjustments to improve the satisfaction indicator. This is how BDA enables the improvement of key educational performance indicators such as student retention and success [85]. Other studies have focused on specific aspects such as evaluating the courses' contents and their effectiveness in the learning process [86]; improving graduate employability based on the study of learning and competencies, human resource strategy, and market dynamics [87]; predicting teacher morality levels and teacher ability [88]; and predicting candidate research focus and tuition fees [89].

Despite the growing number of studies analyzing BDA and its impact on performance, the extant studies are few and fragmented, especially in social sciences [90], and little attention has been paid within HEIs [18,42]. Additionally, although studies have been conducted in various industries that acknowledge its positive impact, other studies still find its influence on organizational performance to be diffuse, [40] as investments in BDA technologies have not provided any direct benefits or improved outcomes [41]. Thus, the impact of BDA capabilities as a competitive factor needs to be further developed [11,90]. Therefore, the following hypothesis is proposed:

Hypothesis $\mathbf{8}$ (H8). The adoption of BDA positively influences the organizational performance of HEIs.

1.1.3. Relationship between KM Processes and BDA and Its Mediating Role with Organizational Performance

For BDA to generate superior organizational performance, KM practices are required that use the knowledge generated efficiently [39] as making the most of the knowledge assets obtained is the purpose of KM [91]. KM processes are important in HEIs because of their contribution to performance [46,92]; as postulated by the knowledge-based view theory [93], effective management of knowledge-based resources and implementation of $\mathrm{KM}$ processes is necessary to achieve superior organizational performance [94]. From the knowledge-based view, an organization is a component of knowledge resources that are valuable, inimitable, and rare in nature [93]; this valuable knowledge must be properly managed through the processes of knowledge acquisition, sharing, and utilization [95]. 
The present study adopts as a guide the KM processes of Darroch [96], who defines a compact view as the acquisition, dissemination, and utilization of knowledge. In the HEI environment, these processes not only enhance collective organizational learning and decision making but also improve productivity and profitability through innovative ideas, product and service novelties [46,92], and the research performance of universities [97].

The interdependence between BDA and KM processes not only enables knowledge generation but also knowledge-sharing and human knowledge extension, resulting in different types of improvements in firm performance [2,53]. To improve organizational performance, companies can generate knowledge using BDA [39], which enables KM processes by providing a large base of information that can be converted into usable knowledge [11,39,42]. This information must be assimilated, distributed, and managed within the organization, and KM processes are critical to allow this knowledge to be fully leveraged and produce evidence-based knowledge products for improved business competence [98-100].

KM processes could be defined as strategies to generate knowledge products aligned with an organization's business objectives [51]; this knowledge is then shared with stakeholders and directed in a timely manner [100]. Despite their relationship, little research has denoted the importance of BDA within KM for achieving superior organizational performance [53], and while some research provides empirical evidence of the relationship [48,49], with others have more critical views of it [50-52]. Previous studies find that some of the value derived from investments in BDA information systems has yielded mixed results [51,53]; in fact, while some studies have argued that BDA and KM do not necessarily lead to better organizational performance or that KM has a partial mediating effect between BDA and organizational performance [39], other studies have found positive associations between the two [53]. Previous research established that KM processes significantly influence organizational performance in HEIs [101-103]; some authors even highlight their contribution in terms of measures such as innovativeness or new product introduction [104].

HEIs are under constant pressure to improve their curricula and produce quality graduates, and these challenges are even greater in developing countries [105]. While the importance of KM in achieving superior and sustainable organizational performance has been recognized and recent literature has confirmed a positive and significant relationship between KM processes and organizational performance [46,106,107], other studies have argued that KM processes offer inconsistent support for improving firm outcomes [104,108]; furthermore, little research has been conducted in the education sector [45,46,109], particularly on the association between KM processes and HEIs $[110,111]$, and very few HEIs in developing countries actively research or produce new knowledge [109]. Most of the research reviewed on the effects of KM processes on organizational performance has focused on large companies, neglecting application in HEIs as knowledge-driven organizations [101]. Therefore, the following hypotheses are proposed:

Hypothesis 9 (H9). The adoption of BDA positively influences knowledge management processes.

Hypothesis 10 (H10). Knowledge management processes positively influence organizational performance in HEIs.

Hypothesis 11 (H11). Knowledge management processes have a mediating effect between the adoption of BDA and the organizational performance of HEIs.

Based on the above discussion, a theoretical framework is developed and is shown in Figure 1. 


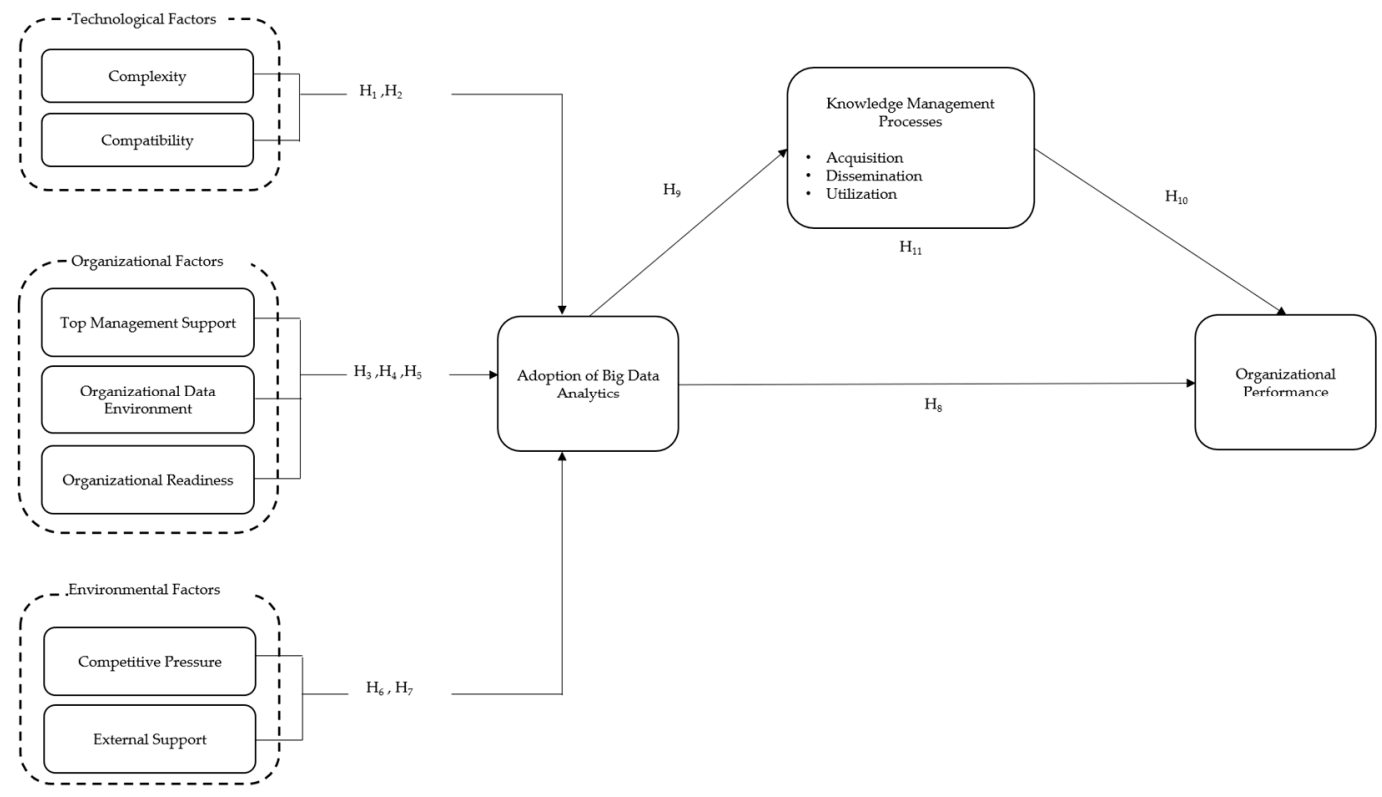

Figure 1. Theoretical framework.

\section{Materials and Methods}

\subsection{Data Collection and Sample}

The present research was developed in Latin America and examined Spanish-speaking HEIs listed in the QS Latin America University Ranking 2021, which comprises a total of 317 HEIs, including those from Argentina, Bolivia, Chile, Colombia, Costa Rica, Cuba, Dominican Republic, Ecuador, El Salvador, Guatemala, Honduras, Mexico, Nicaragua, Panama, Paraguay, Peru, Puerto Rico, Uruguay, and Venezuela. The questionnaire was administered in Spanish, using the double translation method from English to Spanish and Spanish to English to verify its consistency with the original (following the procedure described in [112]) and was validated by BDA experts who are also part of HEIs in Latin America who ensured content validity by examining the relevance, wording, and meaning of each question used in the instrument. The panel of experts introduced modifications to address possible problems related to comprehension and ambiguity, and some indicators were eliminated from the study because they were considered repetitive. A pilot test was also conducted with twenty respondents of different HEIs and suggestions on the presentation of the instrument and the wording of the questions were collected. The measurement indicators used for the constructs are listed in Appendix A.

Given that the method used in this research is structural equation modeling, a final sample of 265 participants was considered in accordance with Kline [113], who suggests that most research of this type use a sample of at least 200 or 5 times the number of parameters considered in the measurement instrument. The selection of the sample was based on a simple random probability sampling, considering as population all those involved in BDA initiatives. According to Chaurasia et al. [37], due to lack of sufficient evidence on how BDA investment could have a positive impact on the performance of HEIs, investigations require respondents have a thorough understanding of BDA with diverse perspectives, considering both practitioners and managers of BDA initiatives in HEIs. For respondents to the questionnaires, we considered teachers, researchers, directors, coordinators, analysts, and data scientists involved in BDA initiatives and actively collaborating in HEIs (adopters) as well as BDA-savvy professionals belonging to HEIs but who had not yet adopted the technology (non-adopters). They were contacted by email and through their professional social networks to inform them of the scope and purpose of the research and to determine whether they were willing to participate. Data collection lasted approximately four months, 
from May to August 2021, and was conducted via online surveys. Table 1 describes the demographic characteristics of the respondents who were part of the study.

Table 1. Respondent characteristics.

\begin{tabular}{ccc}
\hline & Frequency & Percentage \\
\hline Country/ Region of University & 32 & \\
Argentina & 10 & 12.1 \\
Bolivia & 34 & 3.8 \\
Chile & 42 & 12.8 \\
Colombia & 15 & 15.8 \\
Ecuador & 33 & 5.7 \\
Mexico & 7 & 12.5 \\
Paraguay & 28 & 2.6 \\
Peru & 13 & 10.6 \\
Uruguay & 9 & 4.9 \\
Venezuela & 24 & 3.4 \\
Central America & 18 & 8.9 \\
Caribbean & & 6.9 \\
Position & 41 & \\
Analyst or Data Scientist & 9 & 15.5 \\
Assistant & 16 & 3.4 \\
Coordinator & 33 & 6 \\
Director & 42 & 12.5 \\
Researcher & 124 & 15.8 \\
Professor & & 46.8 \\
Adoption Level & 176 & 66.4 \\
Adopter & 89 & 33.6 \\
Non-Adopter & &
\end{tabular}

The present research made use of the key informant approach to data collection to identify HEI members who are involved in or knowledgeable about BDA [114]. To qualify the respondents, the concept of BDA was explained to them, and they were asked to self-rate themselves as adopter, non-adopter, or not aware of the concept; finally, responses from those who were not aware of the concept were excluded.

\subsection{Measurements}

For the development of the present research, the 53 measurement items used are taken from existing research and are considered reliable as they meet the generally accepted threshold value of 0.7 for Cronbach's alpha [115]. The questionnaire employed a sevenpoint Likert scale ranging from " 1 " meaning "strongly disagree" to " 7 " meaning "strongly agree". Regarding the dependent variable-organizational performance-the present study is based on the research of Iqbal et al. [46]; a Cronbach's alpha of 0.81 is obtained for this instrument and it is a first-order construct that has 5 indicators.

For the mediating variable, KM processes, the instruments used by Ngoc-Tan and Gregar [45] and Iqbal et al. [46], are employed; this is a second-order construct that is operationalized through the first-order constructs: knowledge acquisition, knowledge dissemination, and knowledge utilization. Knowledge acquisition is a first-order construct that has 6 indicators; knowledge dissemination is a first-order construct that has 5 indicators, while knowledge utilization is a first-order construct that has 5 indicators. All constructs obtained Cronbach's alpha greater than 0.7 in previous research. Regarding the adoption of BDA, the present study is based on the research of Ji-fan Ren et al. [116]; for this instrument, a Cronbach's alpha greater than 0.7 is obtained. Regarding the technological, organizational, and environmental factors, the instruments used by Verma and Chaurasia [27] and Maroufkhani et al. [33] are used. Technological factors, namely, complexity and compatibility, have 4 indicators each; organizational factors, namely, top management support, data environment, and organizational readiness, have 4 indicators each; while 
environment factors, namely, competitive pressure and external support, have 3 indicators each. All constructs obtained a Cronbach's alpha greater than 0.7 in the previous research.

\subsection{Method}

The method of data analysis used is structural equation modeling based on estimation through a maximum likelihood function. Previously, a confirmatory factor analysis was performed to determine that all constructs used in this study yield favorable results in the tests of convergent, discriminant, and composite reliability (CR) validity. Confirmatory factor analysis, as described by Chion and Charles [117], is used to validate theoretical models from data obtained from indicator variables. In addition, as noted by Kline [118], confirmatory factor analysis is a necessary step in the development of structural equations.

\section{Results}

The reliability of the measurements is assessed prior to data analysis using Cronbach's $\alpha$ coefficient and considering a score of 0.7 as the lower acceptable threshold for each construct [119]. As shown in Table 2, all constructs have Cronbach's $\alpha$ coefficients greater than 0.7 , indicating an acceptable level of reliability.

Table 2. Reliability analysis.

\begin{tabular}{ccc}
\hline Construct & $\alpha$ & Mean \\
\hline BDA Adoption (BDA) & 0.875 & 5.686 \\
Complexity (CPX) & 0.917 & 4.433 \\
Compatibility (CMT) & 0.865 & 5.242 \\
Top Management Support (TMS) & 0.91 & 4.843 \\
Organizational Data Environment (ODE) & 0.877 & 5.202 \\
Organizational Readiness (ORR) & 0.915 & 4.492 \\
Competitive Pressure (COP) & 0.89 & 4.839 \\
External Support (EXS) & 0.839 & 5.075 \\
Knowledge Acquisition (KWA) & 0.835 & 5.266 \\
Knowledge Dissemination (KWD) & 0.866 & 5.504 \\
Knowledge Utilization (KWU) & 0.833 & 5.144 \\
Organizational Performance (ORP) & 0.902 & 5.254 \\
\hline
\end{tabular}

\subsection{Confirmatory Factor Analysis}

Initial confirmatory factor analysis is performed for each construct; factor loads $\geq 0.7$, composite reliability $(\mathrm{CR}) \geq 0.7$, and average variance extracted $(\mathrm{AVE}) \geq 0.5$ are considered for convergent validity and reliability analysis [120-122], and goodness-of-fit tests were performed. Indicators with factor loads less than 0.7 (BDA3, CMT11, KWA33, KWD41, and KWU46) are removed from the analysis. In a second confirmatory factor analysis with factor loads greater than 0.7 , the average variances extracted (AVE) are greater than 0.5 and the composite reliability (CR) of each construct is greater than 0.7, as shown in Table 3 .

Further, the goodness-of-fit tests obtains favorable results [123-125]; first, the goodnessof-fit index (GFI) is 0.840, indicating an acceptable fit. Furthermore, the root mean square residual value (RMSR) is 0.04 , which is within the model's acceptance range, which allows us to conclude that the model in general presents an acceptable absolute fit. The incremental goodness of fit indicators, such as the comparative fit index $(\mathrm{CFI}=0.964)$ and the Tucker-Lewis index (TLI $=0.960)$, show consistent results. Finally, parsimony indicators such as AGFI (Adjusted Goodness of Fit Index $=0.8407$ ), normalized chi-square $\left(\chi^{2}=1.2757\right)$, and RMSEA (0.0372) also meet the acceptance criteria.

To analyze discriminant validity, the square root of the AVE value and the correlations between the constructs in the model are compared. To ensure discriminant validity, the squared correlation coefficients between any pair of constructs must be lower than the AVE for each construct [121,126], as shown in Table 4. 
Table 3. Convergent validity and composite reliability.

\begin{tabular}{|c|c|c|c|c|}
\hline Construct & Item & Loading Factor & CR & AVE \\
\hline \multirow[t]{5}{*}{ BDA Adoption } & BDA1 & 0.860 & 0.919 & 0.695 \\
\hline & BDA2 & 0.752 & & \\
\hline & BDA4 & 0.890 & & \\
\hline & BDA5 & 0.856 & & \\
\hline & BDA6 & 0.802 & & \\
\hline \multirow[t]{4}{*}{ Complexity } & CPX7 & 0.863 & 0.919 & 0.738 \\
\hline & CPX8 & 0.854 & & \\
\hline & CPX9 & 0.853 & & \\
\hline & CPX10 & 0.867 & & \\
\hline \multirow{3}{*}{ Compatibility } & CMT12 & 0.844 & 0.854 & 0.661 \\
\hline & WCL13 & 0.756 & & \\
\hline & WCL14 & 0.836 & & \\
\hline \multirow[t]{4}{*}{ Top Management Support } & TMS15 & 0.806 & 0.913 & 0.725 \\
\hline & TMS16 & 0.779 & & \\
\hline & TMS17 & 0.916 & & \\
\hline & TMS18 & 0.896 & & \\
\hline \multirow[t]{4}{*}{ Organizational Data Environment } & ODE19 & 0.865 & 0.881 & 0.650 \\
\hline & ODE20 & 0.796 & & \\
\hline & ODE21 & 0.800 & & \\
\hline & ODE22 & 0.761 & & \\
\hline \multirow[t]{4}{*}{ Organizational Readiness } & ORR23 & 0.854 & 0.915 & 0.729 \\
\hline & ORR24 & 0.831 & & \\
\hline & ORR25 & 0.853 & & \\
\hline & ORR26 & 0.876 & & \\
\hline \multirow[t]{3}{*}{ Competitive Pressure } & COP27 & 0.846 & 0.891 & 0.731 \\
\hline & COP28 & 0.882 & & \\
\hline & COP29 & 0.836 & & \\
\hline \multirow[t]{3}{*}{ External Support } & EXS30 & 0.849 & 0.840 & 0.638 \\
\hline & EXS31 & 0.746 & & \\
\hline & EXS32 & 0.797 & & \\
\hline \multirow[t]{5}{*}{ Knowledge Acquisition } & KWA34 & 0.782 & 0.880 & 0.595 \\
\hline & KWA35 & 0.786 & & \\
\hline & KWA36 & 0.739 & & \\
\hline & KWA37 & 0.750 & & \\
\hline & KWA38 & 0.797 & & \\
\hline \multirow[t]{4}{*}{ Knowledge Dissemination } & KWD39 & 0.781 & 0.858 & 0.601 \\
\hline & KWD40 & 0.763 & & \\
\hline & KWD42 & 0.748 & & \\
\hline & KWD43 & 0.808 & & \\
\hline \multirow[t]{4}{*}{ Knowledge Utilization } & KWU44 & 0.774 & 0.887 & 0.663 \\
\hline & KWU45 & 0.846 & & \\
\hline & KWU47 & 0.818 & & \\
\hline & KWU48 & 0.817 & & \\
\hline \multirow[t]{5}{*}{ Organizational Performance } & ORP49 & 0.786 & 0.897 & 0.637 \\
\hline & ORP50 & 0.825 & & \\
\hline & ORP51 & 0.883 & & \\
\hline & ORP52 & 0.768 & & \\
\hline & ORP53 & 0.719 & & \\
\hline
\end{tabular}

Likewise, Figure 2 shows the model developed in AMOS SPSS 24 with the different correlations between the latent variables. It is recommended to perform this analysis including all the latent variables, endogenous and exogenous, correlated with each other to statistically verify whether all the variables are different [117]. 
Table 4. Discriminant validity.

\begin{tabular}{|c|c|c|c|c|c|c|c|c|c|c|c|c|}
\hline & ORR & BDA & CPX & CMT & TMS & ODE & COP & EXS & KWA & KWD & KWU & ORP \\
\hline ORR & 0.854 & & & & & & & & & & & \\
\hline BDA & 0.050 & 0.833 & & & & & & & & & & \\
\hline CPX & 0.241 & -0.040 & 0.859 & & & & & & & & & \\
\hline CMT & -0.145 & 0.339 & -0.160 & 0.813 & & & & & & & & \\
\hline TMS & -0.221 & 0.116 & 0.004 & 0.402 & 0.851 & & & & & & & \\
\hline ODE & 0.389 & 0.183 & 0.305 & -0.091 & 0.040 & 0.806 & & & & & & \\
\hline COP & 0.166 & 0.131 & 0.103 & 0.270 & 0.234 & 0.350 & 0.855 & & & & & \\
\hline EXS & 0.096 & 0.321 & 0.114 & 0.270 & 0.235 & 0.257 & 0.361 & 0.798 & & & & \\
\hline KWA & -0.116 & 0.239 & -0.143 & 0.353 & 0.278 & 0.083 & 0.247 & 0.232 & 0.771 & & & \\
\hline KWD & -0.167 & 0.262 & -0.090 & 0.334 & 0.425 & 0.080 & 0.204 & 0.169 & 0.713 & 0.775 & & \\
\hline KWU & -0.158 & 0.129 & -0.104 & 0.315 & 0.389 & -0.047 & 0.184 & 0.132 & 0.643 & 0.698 & 0.814 & \\
\hline ORP & -0.207 & 0.038 & -0.015 & 0.236 & 0.401 & -0.065 & 0.167 & 0.193 & 0.455 & 0.542 & 0.545 & 0.798 \\
\hline
\end{tabular}

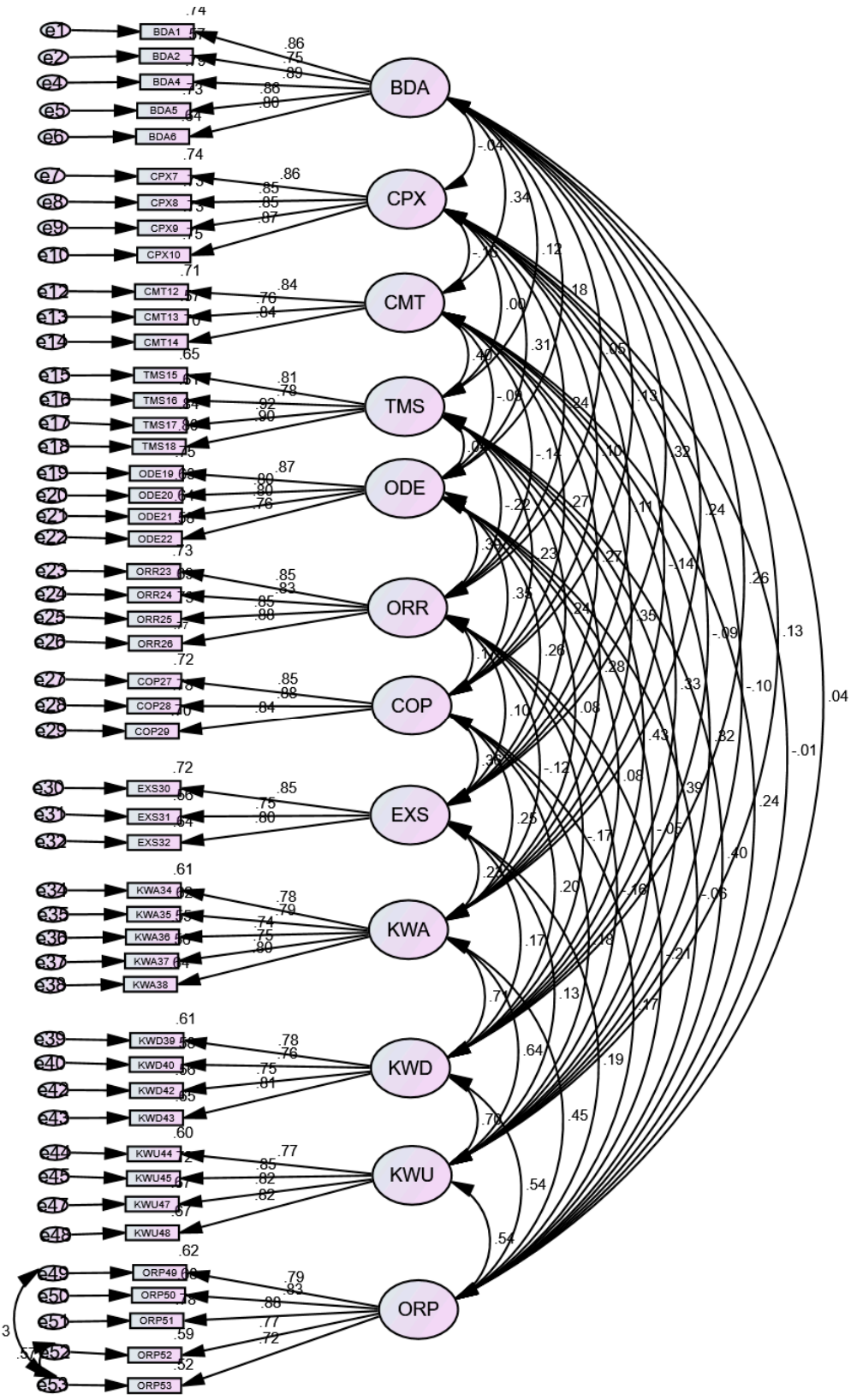

Figure 2. Final CFA model with standardized estimates. 


\subsection{Structural Equation Model}

Having determined that the measurement model has an acceptable level of reliability and validity, we move to the next stage of data analysis: the structural model for hypothesis testing, in which seven hypotheses are accepted and four are rejected (See Table 5). Complexity has no significant impact on BDA adoption $(\beta=-0.056, p>0.05)$, so the first research hypothesis (H1) that complexity negatively influences BDA adoption in HEIs is rejected. Compatibility has a significant impact on BDA adoption $(\beta=0.361, p<0.001)$, thus supporting the second research hypothesis (H2), which asserts that compatibility positively influences BDA adoption in HEIs.

Table 5. Results of the hypothesis tests.

\begin{tabular}{cccccc}
\hline Hypothesis & Relationship & Path Coeff & Std. Error & $\boldsymbol{p}$-Value & Hypothesis \\
\hline H1 & CPX -> BDA & -0.056 & 0.05 & 0.266 & Rejected \\
H2 & CMT - BDA & 0.361 & 0.082 & $* * *$ & Accepted \\
H3 & TMS -> BDA & -0.019 & 0.051 & 0.713 & Rejected \\
H4 & ODE -> BDA & 0.182 & 0.07 & $0.009 *$ & Accepted \\
H5 & ORR -> BDA & 0.017 & 0.047 & 0.717 & Rejected \\
H6 & COP -> BDA & -0.051 & 0.057 & 0.371 & Rejected \\
H7 & EXS -> BDA & 0.212 & 0.064 & $* * *$ & Accepted \\
H8 & BDA - ORP & -0.128 & 0.059 & $0.031 *$ & Accepted \\
H9 & BDA -> KMP & 0.206 & 0.056 & $* * *$ & Accepted \\
H10 & KMP -> ORP & 0.831 & 0.11 & $* * *$ & Accepted \\
H11 & BDA -> KMP -> ORP & 3.307 & 0.052 & 0.001 & Accepted \\
\hline
\end{tabular}

${ }_{* * *} p<0.001 ;{ }^{*} p<0.05$.

Top management support has no significant impact on BDA adoption $(\beta=-0.019$, $p>0.05)$; thus, the third research hypothesis $(\mathrm{H} 3)$ is rejected. A suitable organizational data environment has a significant impact on BDA adoption $(\beta=0.182, p<0.01)$, supporting the fourth research hypothesis (H4). Organizational readiness has no significant impact on BDA adoption ( $\beta=0.017, p>0.05)$; thus, the fifth research hypothesis (H5) is rejected.

Competitive pressure has no significant impact on BDA adoption $(\beta=-0.051, p>0.05)$, contradicting the sixth research hypothesis (H6). External support has a significant impact on BDA adoption ( $\beta=0.212, p<0.001)$, supporting the seventh research hypothesis (H7).

BDA adoption has a significant impact on organizational performance $(\beta=-0.128$, $p<0.05)$; thus, the eighth research hypothesis $(\mathrm{H} 8)$ is accepted. BDA adoption has a significant impact on KM processes $(\beta=0.206, p<0.001)$, supporting the ninth research hypothesis (H9). KM processes have a significant impact on organizational performance ( $\beta=0.831, p<0.001)$, supporting the tenth research hypothesis (H10). Finally, for the evaluation of the eleventh hypothesis (H11), Sobel's test [127] is used, confirming that KM processes have a mediating effect between BDA adoption and organizational performance of HEIs (Sobel's statistic $=3.307, p=0.001$ ).

Figure 3 shows the path diagram of the structural model developed in AMOS SPSS 24. 


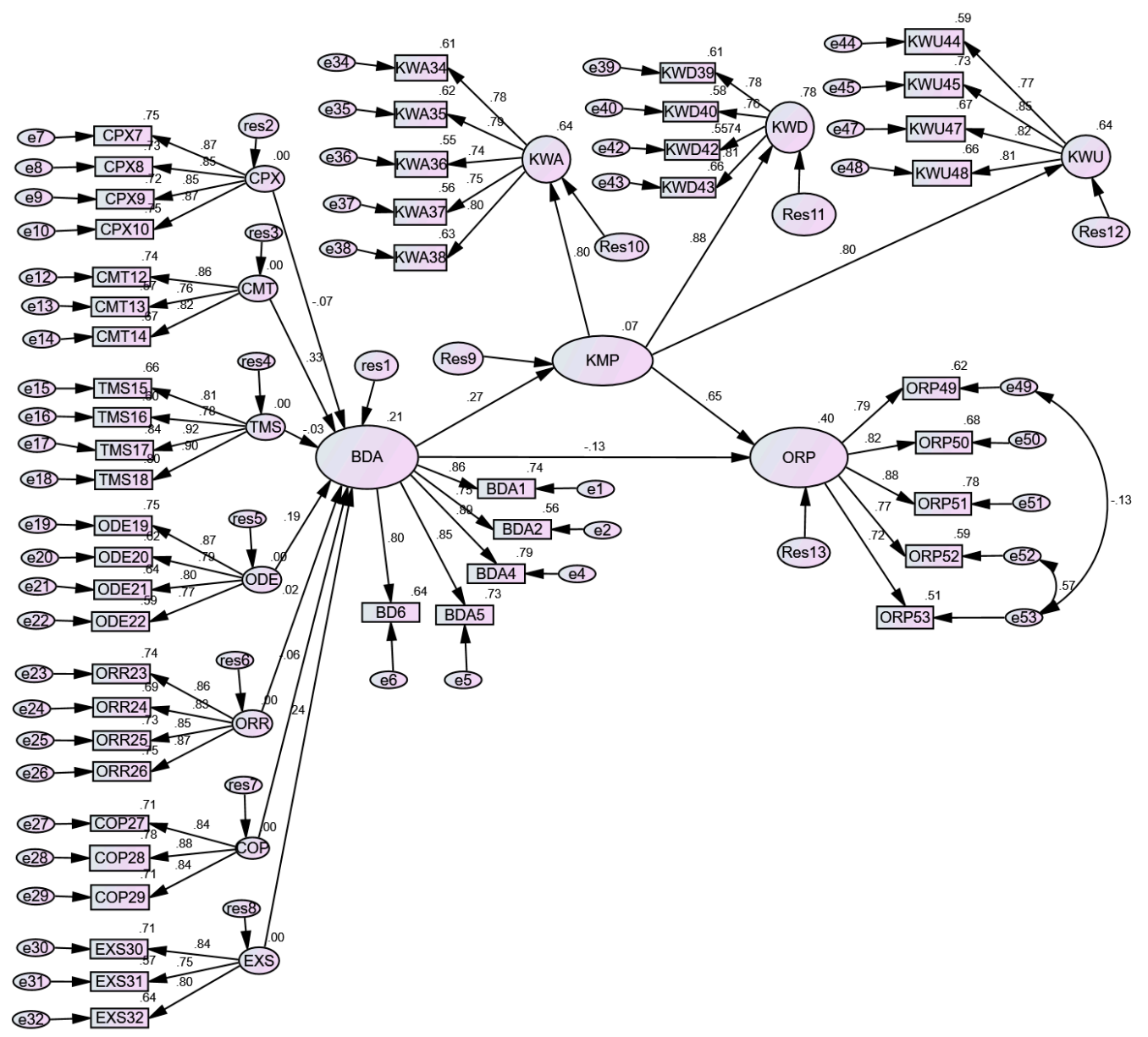

Figure 3. Analysis of the proposed model by estimating coefficients using a maximum likelihood function.

\section{Discussion: Big Data, and Open Innovation}

The main objective of this study is to identify the factors that influence the adoption of BDA, as well as to understand the impact of BDA on organizational performance in higher education and the mediating effect of KM processes. The findings of the study show that, regarding technological factors, complexity has a negligible effect on BDA adoption, inconsistent with the findings obtained in other researches [29,33]. This may be due to the early stage of the adoption of BDA in the education sector compared to other sectors [24], and in developing countries in Latin America, complexity is not yet perceived as it has not been applied in complex use cases that require the processing of several sources of information. However, compatibility has a significant effect on BDA adoption, consistent with previous studies $[32,65]$.

Regarding organizational factors, a suitable organizational data environment has a significant effect on BDA adoption, consistent with previous studies [27,66]; the authors of these studies stated that with sufficient agreement, protocols, and architecture, companies could easily adopt BDA. However, top management support and organizational readiness have negligible impacts in contrast to the results of other studies $[29,128]$. This may be because $\mathrm{BDA}$ implementation is currently taking place at the level of faculty and not at the level of HEI as a whole, not requiring direct top management support or a large investment in resources.

Regarding environmental factors, external support has a significant effect on BDA adoption, which was concluded in previous investigations [129] and is consistent with studies that indicate that open innovation requires external collaboration [87,130-132], while competitive pressure has a negligible effect on BDA adoption, consistent with the results of other studies [33] but inconsistent with other results [31,133]. This may be due 
to the early stage of adoption in HEIs, which are using BDA as a process of learning and verifying its potential and not as a necessity triggered by competitive pressure.

The results also indicated that the adoption of BDA has a significant impact on HEI performance, which is consistent with the results of other studies [16,53,60], the authors of which highlight the improvement it can bring to indicators such as learning effectiveness and the competitive advantages that are achieved from open innovation generated by the use of BDA [29,134-136]. Likewise, a significant relationship was found between KM processes and HEI performance, corroborating the findings of authors $[46,107,137]$ who argue that the effective implementation of KM processes can present a sustainable competitive advantage, considering HEIs as an open innovator that promotes the exchange of knowledge [138-141]. Finally, we found that knowledge management processes act as mediating factors in the relationship between BDA adoption and organizational performance, consistent with research such as that of Shabbir and Gardezi [39].

\section{Conclusions}

The current study aimed to examine which factors influence the adoption of BDA in HEIS; it also reveals the impact that the adoption of the BDA has on organizational performance mediated by KM processes. This study concludes that factors such as compatibility with existing information systems, an adequate organizational data environment, and external support are necessary for the adoption of BDA in Latin American HEIs. The study also reveals the positive impact of BDA on organizational performance mediated by $\mathrm{KM}$ processes. Based on the literature reviewed and the findings of this study, it is important to highlight that BDA is adopted under a holistic view that considers technological, organizational, and environmental factors, and that the knowledge obtained is managed through KM processes to achieve the expected results. Therefore, it is recommended that decision-makers in HEIs promote BDA and KM adoption initiatives, generating dynamic capabilities that consider aspects identified in this research.

The results of the research also invite reflections on the importance of adopting BDA and KM processes; the large amount of information that HEIs can extract and analyze from internal and external sources in digital environments through BDA make it necessary to adopt this technology because it generates opportunities for open innovation and the consequent creation of new products and services. This process is enhanced in the context of the pandemic because it has allowed universities to add value to society by preparing increasingly skilled professionals $[134,138]$. New curricula are created that constantly adapt to society's needs, and there are consultancies focused on little-studied but fundamental aspects; moreover, the personalization of teaching shows the relevance of adopting BDA and $\mathrm{KM}$ processes, which ultimately allow for the improvement of performance indicators with the help of innovative practices related to technology [135].

This study is significant because it is one of the first to propose a theoretical model that integrates the factors that influence the adoption of $\mathrm{BDA}, \mathrm{KM}$ processes, and organizational performance, and which can be replicated in various industries. On the other hand, this study is significant because it identifies the factors that influence the adoption of the BDA and should be considered by decision-makers involved in or in charge of defining the implementation strategy of BDA in HEIs. Finally, this research is important because it shows the need to incorporate KM processes as part of the BDA implementation strategy, which allows for the acquisition, dissemination, and use of the knowledge generated to obtain a better organizational performance.

\subsection{Theoretical Contributions}

This study answers the questions about the main factors of BDA adoption and its impact on HEI performance. Although there are several studies on BDA, few relate to the factors that influence its adoption [25,55]. Further, previous studies yielded different conclusions about the factors depending on the sector where they were developed; therefore, further empirical findings of its application are needed [25]. In particular, it is one of the 
first studies to integrate the study of BDA adoption factors in the education sector and examines the mediating effect of KM processes between BDA and organizational performance in an integrated theoretical framework, noting the importance of the acquisition, dissemination, and use of the generated knowledge.

\subsection{Practical Contributions}

This study provides several suggestions for researchers, practitioners, administrators, and decision-makers involved in or in charge of defining the implementation strategy of BDA in HEIs. First, the study identifies the factors that influence the adoption of BDA, and which should be considered by the members of the universities that are defining the strategy for the introduction of this technology. Regarding compatibility, the findings show the importance of defining a flexible architecture that is compatible with the systems that currently exist in the organization to store data that enables the possibility of performing analytical tasks; this will allow for simple, early adoption that generates short-term results and obtains the confidence of senior management for the future. Regarding an adequate organizational data environment, this will be achieved based on the definition of official data sources that are part of the defined architecture and mitigate the possibility of generating information silos; this will also allow one to establish clear agreements on the definitions and use of data, and the creation of a common data dictionary [142]. Finally, regarding external support, the findings show the importance of acquiring skills for the use of BDA within the organization, and this can be achieved with the support of specialist providers that provide training and support in the first steps of adoption.

Second, the study identifies the mediating effect of KM processes to achieve the expected organizational performance; this finding reflects the importance of defining, within BDA adoption strategy, an adequate framework to acquire the knowledge that can be generated and to establish procedures to disseminate it for use by university members. These mechanisms must be defined beforehand, so that the investment in technology yields the expected results.

Finally, the study reveals the positive impact of BDA on organizational performance. For this positive impact to be achieved by HEIs, it is important to define the scenarios that are sought to be solved and the indicators that will improve as a function of its application; indicators such as customer satisfaction, in this case the students, or the increase in research productivity are suggested as some key indicators to consider.

\subsection{Limitations and Future Research Directions}

This study has several limitations. First, this study considers HEIs; therefore, it is not recommended that the findings of this study be generalized to other sectors, but that they instead be first studied, after which comparisons can be made. Thus, it is recommended that future research apply the theoretical model developed in the present study as this will allow its validity to be assessed in other sectors and countries. Second, the study takes a quantitative approach to data analysis; in view of the constant evolution of this technology, it is recommended that a qualitative approach be considered to allow for contrasts and the identification of factors that influence the adoption of BDA. Third, as the study was conducted at a specific moment, it did not allow one to observe the changes produced by the adoption of BDA. A longitudinal study is thus necessary to evaluate the relationships of the variables used in the proposed theoretical framework to deliver more accurate results, and in Latin America in particular, where the greater development of this technology in HEIs could produce important results in the coming years.

Author Contributions: Conceptualization, G.F.M.S. and I.D.L.V.; methodology, G.F.M.S. and I.D.L.V.; software, G.F.M.S.; validation, G.F.M.S. and I.D.L.V.; formal analysis, G.F.M.S.; investigation, G.F.M.S.; data curation, G.F.M.S.; writing—original draft preparation, G.F.M.S.; writing-review and editing, I.D.L.V.; visualization, G.F.M.S.; supervision, I.D.L.V. All authors have read and agreed to the published version of the manuscript. 
Funding: This research received no external funding.

Institutional Review Board Statement: Not applicable.

Informed Consent Statement: Informed consent was obtained from all subjects involved in the study.

Data Availability Statement: The data presented in this study are openly available in FigShare at https://doi.org/10.6084/m9.figshare.16606700.v1.

Conflicts of Interest: The authors declare no conflict of interest.

\section{Appendix A}

Table A1. Construct items.

\begin{tabular}{|c|c|}
\hline Constructs & Items \\
\hline BDA Adoption & $\begin{array}{l}\text { BDA 1-Big Data Analytics improves the quality of work } \\
\text { BDA 2-Big Data Analytics makes work more efficient } \\
\text { BDA 3-Big Data Analytics reduces costs } \\
\text { BDA 4-Big Data Analytics improves customer service } \\
\text { BDA 5-Big Data Analytics attracts new sales to new customers or new markets } \\
\text { BDA 6-The adoption of Big Data Analytics identifies new product/service opportunities }\end{array}$ \\
\hline Complexity & $\begin{array}{l}\text { CPX 7-It is difficult to normalize huge amount of unstructured data from multiple sources to make it } \\
\text { compatible with structured data } \\
\text { CPX 8-After analyzing big data, interpretation of results to extract actionable knowledge has been difficult } \\
\text { CPX 9-It is difficult to integrate data across multiple incompatible databases among various stakeholders } \\
\text { CPX 10-It is difficult to integrate data across silos }\end{array}$ \\
\hline Compatibility & $\begin{array}{l}\text { CMT 11-BDA provides flexible architecture, which is compatible to various analytical tasks } \\
\text { CMT 12-BDA architecture is compatible with schemas used for storing data } \\
\text { CMT 13-BDA is compatible with existing technological architecture } \\
\text { CMT 14-It is easy to synchronize external data with organization's internal data }\end{array}$ \\
\hline $\begin{array}{c}\text { Top management } \\
\text { support }\end{array}$ & $\begin{array}{l}\text { TMS 15-Top management has generally been likely to take risks involved in the adoption of the BDA } \\
\text { TMS 16-Top management is likely to consider the adoption of BDA, which is strategically important } \\
\text { TMS 17-Top management have policies that encourage usage of BDA initiatives to streamline, monitor, and } \\
\text { maintain enterprise's data flow } \\
\text { TMS 18-Top management have strong positive views on how BDA could transform business }\end{array}$ \\
\hline $\begin{array}{c}\text { Organizational } \\
\text { data environment }\end{array}$ & $\begin{array}{l}\text { ODE 19-Big data is fragmented and dispersed among various stakeholders } \\
\text { ODE 20-Lack of metadata across different silos exists presently } \\
\text { ODE } 21-\text { Usage of BDA could increase the vulnerability of sensitive data to be exposed } \\
\text { ODE } 22 \text { - A clear agreement on a common set of big data definitions and business rules is required in my } \\
\text { organizations }\end{array}$ \\
\hline $\begin{array}{l}\text { Organizational } \\
\text { readiness }\end{array}$ & $\begin{array}{l}\text { ORR 23-Lacking capital/financial resources has prevented my company from fully exploit Big Data } \\
\text { Analytics } \\
\text { ORR 24-Lacking needed IT infrastructure has prevented my company from exploiting Big Data Analytics } \\
\text { ORR 25-Lacking analytics capability prevented the business form fully exploiting Big Data Analytics } \\
\text { ORR 26-Lacking skilled resources prevented the business from fully exploiting Big Data Analytics }\end{array}$ \\
\hline $\begin{array}{l}\text { Competitive } \\
\text { pressure }\end{array}$ & $\begin{array}{l}\text { COP 27-Our choice to adopt Big Data Analytics would be strongly influenced by what competitors in the } \\
\text { industry are doing } \\
\text { COP } 28 \text {-Our firm is under pressure from competitors to adopt Big Data Analytics } \\
\text { COP } 29 \text {-Our firm would adopt Big Data Analytics in response to what competitors are doing }\end{array}$ \\
\hline External support & $\begin{array}{l}\text { EXS 30-Community agencies/vendors can provide required training for Big Data Analytics adoption } \\
\text { EXS 31-Community agencies/vendors can provide effective technical support for Big Data Analytics } \\
\text { adoption } \\
\text { EXS 32-Vendors actively market Big Data Analytics adoption }\end{array}$ \\
\hline
\end{tabular}


Table A1. Cont.

\begin{tabular}{|c|c|}
\hline Constructs & Items \\
\hline $\begin{array}{l}\text { Knowledge } \\
\text { Acquisition }\end{array}$ & $\begin{array}{l}\text { KWA 33-We hire new employees as a source for acquiring new knowledge } \\
\text { KWA 34-We provide an open environment to our employees acquire new knowledge } \\
\text { KWA 35-We actively observe and adopt the best practice in our sector } \\
\text { KWA 36-We continually gather information that is relevant to our operations and activities } \\
\text { KWA 37-We list and define the knowledge we possess as well as any unavailable knowledge } \\
\text { KWA 38-We obtain knowledge from different sources: customers, partners, and employees }\end{array}$ \\
\hline $\begin{array}{l}\text { Knowledge } \\
\text { Dissemination }\end{array}$ & $\begin{array}{l}\text { KWD 39-We share information and knowledge necessary to complete tasks } \\
\text { KWD 40-We exchange knowledge between employees to achieve our goals with little time and effort } \\
\text { KWD 41-We developed information systems, such as intranet and electronic bulletin boards, to share } \\
\text { information and knowledge } \\
\text { KWD 42-We promote sharing of information and knowledge between team members and the various units } \\
\text { KWD 43-Knowledge is shared between supervisors and subordinates }\end{array}$ \\
\hline $\begin{array}{l}\text { Knowledge } \\
\text { Utilization }\end{array}$ & $\begin{array}{l}\text { KWU 44-My institution has methods to analyze and critically evaluate knowledge to generate new patterns } \\
\text { and knowledge for future use } \\
\text { KWU 45-My institution applies knowledge to critical competitive needs } \\
\text { KWU 46-My institution has mechanism to protect knowledge from inappropriate or illegal use inside and } \\
\text { outside of the institution } \\
\text { KWU } 47-\text { My institution has different methods to further develop knowledge and apply it to new situations } \\
\text { KWU 48-My institution has mechanism for filtering, cross-listing, and integrating different sources and } \\
\text { types of knowledge }\end{array}$ \\
\hline $\begin{array}{l}\text { Organizational } \\
\text { Performance }\end{array}$ & $\begin{array}{l}\text { OPR 49-Customer satisfaction of our organization is better than our key competitors' } \\
\text { OPR 50-Quality development of our organization is better than our key competitors' } \\
\text { OPR 51-Responsiveness of our organization is better than our key competitors' } \\
\text { OPR 52-Research productivity of our organization is better than our key competitors' } \\
\text { OPR 53-Research ranking of our organization is better than our key competitors' }\end{array}$ \\
\hline
\end{tabular}

\section{References}

1. Chakraborty, C.; Bhattacharya, M.; Sharma, A.R.; Lee, S.S.; Agoramoorthy, G. SARS-CoV-2 Brazil variant in Latin America: More serious research urgently needed on public health and vaccine protection. Ann. Med. Surg. 2021, 10, 102428. [CrossRef]

2. Iacuzzi, S.; Fedele, P.; Garlatti, A. Beyond Coronavirus: The role for knowledge management in schools responses to crisis. Knowl. Manag. Res. Pract. 2020, 1-6. [CrossRef]

3. Sukendro, S.; Habibi, A.; Khaeruddin, K.; Indrayana, B.; Syahruddin, S.; Makadada, F.A.; Hakim, H. Using an extended Technology Acceptance Model to understand students' use of e-learning during Covid-19: Indonesian sport science education context. Heliyon 2020, 6, e05410. [CrossRef]

4. Matthews, A.; McLinden, M.; Greenway, C. Rising to the pedagogical challenges of the Fourth Industrial Age in the university of the future: An integrated model of scholarship. High. Educ. Pedagog. 2021, 6, 1-21. [CrossRef]

5. Webb, A.; McQuaid, R.W.; Webster, C.W.R. Moving learning online and the COVID-19 pandemic: A university response. World J. Sci. Technol. Sustain. Dev. 2021, 18. [CrossRef]

6. Packmohr, S.; Brink, H. Impact of the Pandemic on the Barriers to the Digital Transformation in Higher Education-Comparing Pre-and Intra-Covid-19 Perceptions of Management Students. In Proceedings of the International Conference on Business Informatics Research, Vienna, Austria, 22-24 September 2021; pp. 3-18.

7. Sheng, J.; Amankwah-Amoah, J.; Khan, Z.; Wang, X. COVID-19 Pandemic in the New Era of Big Data Analytics: Methodological Innovations and Future Research Directions. Br. J. Manag. 2020. [CrossRef]

8. Almeida, F.; Santos, J.D.; Monteiro, J.A. The Challenges and Opportunities in the Digitalization of Companies in a Post-COVID-19 World. IEEE Eng. Manag. Rev. 2020, 48, 97-103. [CrossRef]

9. Ranjan, J.; Foropon, C. Big data analytics in building the competitive intelligence of organizations. Int. J. Inf. Manag. 2021, 56, 102231. [CrossRef]

10. Abdellatif, M.; Asma, K. A new model for the impact of knowledge management on university performance: Empirical study based on student opinions. J. Inf. Knowl. Manag. 2019, 18, 1950029. [CrossRef]

11. Manesh, M.F.; Pellegrini, M.M.; Marzi, G.; Dabic, M. Knowledge management in the fourth industrial revolution: Mapping the literature and scoping future avenues. IEEE Trans. Eng. Manag. 2020, 68, 289-300. [CrossRef]

12. Velásquez, R.M.A.; Lara, J.V.M. Knowledge management in two universities before and during the COVID-19 effect in Peru. Technol. Soc. 2021, 64, 101479. [CrossRef]

13. Ciampi, F.; Marzi, G.; Demi, S.; Faraoni, M. The big data-business strategy interconnection: A grand challenge for knowledge management. A review and future perspectives. J. Knowl. Manag. 2020, 24, 1157-1176. [CrossRef] 
14. Hargitai, D.M.; Pinzaru, F.; Veres, Z. Integrating Business Students' E-Learning Preferences into Knowledge Management of Universities after the COVID-19 Pandemic. Sustainability 2021, 13, 2478. [CrossRef]

15. Muhammad, R.N.; Tasmin, R.; Aziati, A.N. Sustainable Competitive Advantage of Big Data Analytics in Higher Education Sector: An Overview. J. Phys. Conf. Ser. 2020, 1529, 042100. Available online: https:/ /iopscience.iop.org/article/10.1088/1742-6596/1529 /4/042100/meta (accessed on 20 October 2021). [CrossRef]

16. Sedkaoui, S.; Khelfaoui, M. Understand, develop and enhance the learning process with big data. Inf. Discov. Deliv. 2019, 47. [CrossRef]

17. Tasmin, R.; Muhammad, R.N.; Aziati, A.N. Big Data Analytics Applicability in Higher Learning Educational System. IOP Conf. Ser. Mater. Sci. Eng. 2020, 917, 012064. Available online: https://iopscience.iop.org/article/10.1088/1757-899X/917/1/012064/meta (accessed on 20 October 2021). [CrossRef]

18. Ashaari, M.A.; Singh, K.S.D.; Abbasi, G.A.; Amran, A.; Liebana-Cabanillas, F.J. Big data analytics capability for improved performance of higher education institutions in the Era of IR 4.0: A multi-analytical SEM ANN perspective. Technol. Forecast. Soc. Chang. 2021, 173, 121119. [CrossRef]

19. Blikstein, P. Using learning analytics to assess students' behavior in open-ended programming tasks. In Proceedings of the 1st International Conference on Learning Analytics and Knowledge, Banff, AB, Canada, 27 February-1 March 2011; pp. 110-116.

20. Strang, K.D. Can online student performance be forecasted by learning analytics? Int. J. Technol. Enhanc. Learn. 2016, 8, 26-47. Available online: https:/ / www.inderscienceonline.com/doi/abs/10.1504/IJTEL.2016.075950 (accessed on 20 October 2021). [CrossRef]

21. Papamitsiou, Z.K.; Economides, A.A. Learning analytics and educational data mining in practice: A systematic literature review of empirical evidence. J. Educ. Technol. Soc. 2014, 17, 49-64. Available online: https://www.jstor.org/stable/jeductechsoci.17.4.49 (accessed on 20 October 2021).

22. Shaw, D.; Hall, M.; Edwards, J.S.; Baker, B. Responding to crisis through strategic knowledge management. J. Organ. Chang. Manag. 2007, 20, 559-578. [CrossRef]

23. Park, J.H.; Kim, Y.B. Factors activating big data adoption by Korean firms. J. Comput. Inf. Syst. 2019, 61, 285-293. [CrossRef]

24. Alsheikh, A. Developing an integrated framework to utilize big data for higher education institutions in Saudi Arabia. Int. J. Comput. Sci. Inf. Technol. 2019, 11, 1. Available online: https://ssrn.com/abstract=3358120 (accessed on 20 October 2021). [CrossRef]

25. El-Haddadeh, R.; Osmani, M.; Hindi, N.; Fadlalla, A. Value creation for realising the sustainable development goals: Fostering organisational adoption of big data analytics. J. Bus. Res. 2021, 131, 402-410. [CrossRef]

26. Henao-García, E.; Arias-Pérez, J.; Lozada, N. Fostering big data analytics capability through process innovation: Is management innovation the missing link? Bus. Inf. Rev. 2021, 38, 28-39.

27. Verma, S.; Chaurasia, S. Understanding the determinants of big data analytics adoption. Inf. Resour.Manag. J. 2019, 32, 1-26. [CrossRef]

28. Yadegaridehkordi, E.; Nilashi, M.; Shuib, L.; Nasir, M.H.N.B.M.; Asadi, S.; Samad, S.; Awang, N.F. The impact of big data on firm performance in hotel industry. Electron. Commer. Res. Appl. 2020, 40, 10. [CrossRef]

29. Gangwar, H. Understanding the determinants of big data adoption in India: An analysis of the manufacturing and services sectors. Inf. Resour. Manag. J. 2018, 31, 1-22. [CrossRef]

30. Baig, M.I.; Shuib, L.; Yadegaridehkordi, E. Big data adoption: State of the art and research challenges. Inf. Process. Manag. 2019, 56, 102095. [CrossRef]

31. Nam, D.-W.; Kang, D.-W.; Kim, S. Process of big data analysis adoption: Defining big data as a new IS innovation and examining factors affecting the process. In Proceedings of the 2015 48th Hawaii International Conference on System Sciences, Kauai, HI, USA, 5-8 January 2015; pp. 4792-4801.

32. Verma, S.; Bhattacharyya, S. Perceived strategic value-based adoption of Big Data Analytics in emerging economy: A qualitative approach for Indian firms. J. Enterp. Inf. Manag. 2017, 30, 354-382. [CrossRef]

33. Maroufkhani, P.; Tseng, M.L.; Iranmanesh, M.; Ismail, W.K.W.; Khalid, H. Big data analytics adoption: Determinants and performances among small to medium-sized enterprises. Int. J. Inf. Manag. 2020, 54, 102190. [CrossRef]

34. Chaurasia, S.S.; Rosin, A.F. From Big Data to Big Impact: Analytics for teaching and learning in higher education. Ind. Commer. Train. 2017, 49, 321-328. [CrossRef]

35. Diniz, E.H.; Luvizan, S.S.; Hino, M.C.; Ferreira, P.C. Unveiling the Big Data Adoption in Banks: Strategizing the Implementation of a New Technology Digital Technology and Organizational Change; Springer: Berlin/Heidelberg, Germany, 2018; pp. 149-162.

36. Ijab, M.T.; Wahab, S.M.A.; Salleh, M.A.M.; Bakar, A.A. Investigating Big Data Analytics Readiness in Higher Education Using the Technology Organisation-Environment (TOE) Framework. In Proceedings of the 6th International Conference on Research and Innovation in Information Systems, Johor Bahru, Malaysia, 2-3 December 2019.

37. Chaurasia, S.S.; Kodwani, D.; Lachhwani, H.; Ketkar, M.A. Big data academic and learning analytics: Connecting the dots for academic excellence in higher education. Int. J. Educ. Manag. 2018, 32, 1099-1117. [CrossRef]

38. Akter, S.; Wamba, S.F.; Gunasekaran, A.; Dubey, R.; Childe, S.J. How to improve firm performance using big data analytics capability and business strategy alignment? Int. J. Prod. Econom. 2016, 182, 113-131. [CrossRef]

39. Shabbir, M.Q.; Gardezi, S.B.W. Application of big data analytics and organizational performance: The mediating role of knowledge management practices. J. Big Data 2020, 7, 47. [CrossRef] 
40. Mishra, D.; Luo, Z.; Hazen, B.; Hassini, E.; Foropon, C. Organizational capabilities that enable big data and predictive analytics diffusion and organizational performance: A resource-based perspective. Manag. Decis. 2019, 57, 1734-1755. [CrossRef]

41. Ghasemaghaei, M.; Calic, G. Can big data improve firm decision quality? The role of data quality and data diagnosticity. Decis. Support Syst. 2019, 120, 38-49. [CrossRef]

42. Rialti, R.; Marzi, G.; Caputo, A.; Mayah, K.A. Achieving strategic flexibility in the era of big data: The importance of knowledge management and ambidexterity. Manag. Decis. 2020, 58, 1585-1600. [CrossRef]

43. Majid, A. Yasir, M. Nexus of knowledge-management enablers, trust and knowledge-sharing in research universities. J. Appl. Res. High. Educ. 2017, 9, 424-438.

44. Agrawal, A.; Mukti, S.K. Knowledge Management It's Origin, Success Factors, Planning, Tools, Applications, Barriers and Enablers: A Review. Int. J. Knowl. Manag. 2020, 16, 43-82. [CrossRef]

45. Ngoc-Tan, N.; Gregar, A. Knowledge management and its impacts on organisational performance: An empirical research in public higher education institutions of Vietnam. J. Inf. Knowl. Manag. 2019, 18, 1950015. [CrossRef]

46. Iqbal, A.; Latif, F.; Marimon, F.; Sahibzada, U.F.; Hussain, S. From knowledge management to organizational performance. J. Enterp. Inf. Manag. 2019, 32. [CrossRef]

47. Bao, Q.; Wang, J.; Cheng, J. Research on ontology modeling of steel manufacturing process based on big data analysis. In MATEC Web of Conferences; EDP Sciences: Les Ulis, France, 2016; Volume 45.

48. Peroni, S.; Vitali, F. Interfacing fast-fashion design industries with Semantic Web technologies: The case of Imperial Fashion. J. Web Semant. 2017, 44, 37-53. [CrossRef]

49. Mungai, K.; Bayat, A. The impact of big data on the South African banking industry. In Proceedings of the 15th International Conference on Intellectual Capital 2018, Knowledge Management and Organisational Learning, ICICKM 2018, Cape Town, South Africa, 29-30 November 2018.

50. Obitade, P.O. Big data analytics: A link between knowledge management capabilities and superior cyber protection. J. Big Data 2019, 6, 71. [CrossRef]

51. Pauleen, D.J.; Wang, W.Y. Does big data mean big knowledge? KM perspectives on big data and analytics. J. Knowl. Manag. 2017, 21, 1-6. [CrossRef]

52. Singh, S.K.; Del Giudice, M. Big data analytics, dynamic capabilities and firm performance. Manag. Decis. 2019, 57, 1729-1733. [CrossRef]

53. Ferraris, A.; Mazzoleni, A.; Devalle, A.; Couturier, J. Big data analytics capabilities and knowledge management: Impact on firm performance. Manag. Decis. 2019, 57, 1923-1936. [CrossRef]

54. Chión, S.J.; Charles, V.; Morales, J. The impact of organizational culture, organizational structure and technological infrastructure on process improvement through knowledge sharing. Bus. Process Manag. J. 2019, 26, 1443-1472. [CrossRef]

55. Baig, M.I.; Shuib, L.; Yadegaridehkordi, E. Big data in education: A state of the art limitations, and future research directions. Int. J. Educ. Technol. High. Educ. 2020, 17, 102095. [CrossRef]

56. Popovič, A.; Hackney, R.; Tassabehji, R.; Castelli, M. The impact of big data analytics on firms' high value business performance. Inform. Syst. Front. 2018, 20, 209-222. [CrossRef]

57. Harlow, H.D. Developing a knowledge management strategy for data analytics and intellectual capital. Meditari Account. Res. 2018, 26, 400-419. [CrossRef]

58. O'Leary, D.E. Artificial intelligence and big data. IEEE Intell. Syst. 2013, 28, 96-99. [CrossRef]

59. Lee, I. Big data: Dimensions, evolution, impacts, and challenges. Bus. Horiz. 2017, 60, 293-303. [CrossRef]

60. Wamba, S.F.; Gunasekaran, A.; Akter, S.; Ren, S.J.F.; Dubey, R.; Childe, S.J. Big data analytics and firm performance: Effects of dynamic capabilities. J. Bus. Res. 2017, 70, 356-365. [CrossRef]

61. Lamba, H.S.; Dubey, S.K. Analysis of requirements for big data adoption to maximize IT business value. In Proceedings of the 2015 4th International Conference on Reliability 2015, Infocom Technologies and Optimization (ICRITO), Noida, India, 2-4 September 2015.

62. Tornatzky, L.G.; Fleischer, M. The Processes of Technological Innovation; Lexington Book: Lexington, KY, USA, 1990.

63. Oliveira, T.; Martins, M.F. Firms patterns of e-business adoption: Evidence for the European Union. Electron. J. Inf. Syst. Eval. 2010, 13, 47-56. Available online: https:/ / academic-publishing.org/index.php/ejise/article/view/281 (accessed on 20 October 2021).

64. Lian, J.; Yen, D.; Wang, Y. An exploratory study to understand the critical factors affecting the decision to adopt cloud computing in Taiwan hospital. Int. J. Inf. Manag. 2014, 34, 28-36. [CrossRef]

65. Chen, D.Q.; Preston, D.S.; Swink, M. How the use of big data analytics affects value creation in supply chain management. J. Manag. Inf. Syst. 2015, 32, 4-39. [CrossRef]

66. Lai, Y.; Sun, H.; Ren, J. Understanding the determinants of big data analytics (BDA) adoption in logistics and supply chain management. Int. J. Logist. Manag. 2018, 29. [CrossRef]

67. Xu, W.; Ou, P.; Fan, W. Antecedents of ERP assimilation and its impact on ERP value: A TOE-based model and empirical test. Inf. Syst. Front. 2017, 19, 13-30. [CrossRef]

68. Hu, J.; Vasilakos, A.V. Energy big data analytics and security: Challenges and opportunities. IEEE Trans. Smart Grid 2016, 7, 2423-2436. [CrossRef]

69. Lee, S.; Kim, K. Factors affecting the implementation success of internet-based information systems. Comput. Hum. Behav. 2007, 23, 1853-1880. [CrossRef] 
70. Zhang, K.; Wang, J.; Jiang, C.; Wei, Z.; Ren, Y. Big data driven information diffusion analysis and control in online social networks. In Proceedings of the IEEE International Conference on Communications 2017, Paris, France, 21-25 May 2017; pp. 1-6.

71. Awa, H.; Ukoha, O.; Igwe, S.R. Revisiting technology-organization-environment (T-O-E) theory for enriched applicability. Bottom Line 2017, 30, 2-22. [CrossRef]

72. Shin, D.H. Demystifying big data: Anatomy of big data developmental process. Telecommun. Policy 2016, 40, 837-854. [CrossRef]

73. Ahani, A.; Rahim, N.Z.A.; Nilashi, M. Forecasting social CRM adoption in SMEs: A combined SEM-neural network method. Comput. Hum. Behav. 2017, 75, 560-578. [CrossRef]

74. Zomaya, A.Y.; Sakr, S. Handbook of Big Data Technologies; Springer: Berlin/Heidelberg, Germany, 2017.

75. Ramamurthy, K.; Sen, A.; Sinha, A.P. An empirical investigation of the key determinants of data warehouse adoption. Decis. Support Syst. 2008, 44, 817-841. [CrossRef]

76. Wang, H.; Xu, Z.; Fujita, H.; Liu, S. Towards felicitous decision making: An overview on challenges and trends of big data. Inf. Sci. 2016, 367, 747-765. [CrossRef]

77. Barney, J. Firm resources and sustained competitive advantage. J. Manag. 1991, 17, 99-120. [CrossRef]

78. Amit, R.; Schoemaker, P.J. Strategic assets and organizational rent. Strateg. Manag. J. 1993, 14, 33-46. [CrossRef]

79. Barney, J.B.; Arikan, A.M. The resource-based view: Origins and implications. Blackwell Handb. Strateg. Manag. 2001, 5, 124.

80. Davenport, T.H. Competing on analytics. Harv. Bus. Rev. 2006, 84, 98. Available online: https://hbsp.harvard.edu/product/R060 1H-PDF-SPA (accessed on 20 October 2021).

81. Giacosa, E.; Ferraris, A.; Mazzoleni, A.; Vrontis, D. A model for testing the relationship between company's size and performance: A cross country analysis. Global Bus. Econom. Rev. 2018, 20, 524-543. [CrossRef]

82. Mikalef, P.; Pappas, I.O.; Krogstie, J.; Giannakos, M. Big data analytics capabilities: A systematic literature review and research agenda. Inf. Syst. e-Bus. Manag. 2017, 16, 547-578. [CrossRef]

83. Janssen, M.; van der Voort, H.; Wahyudi, A. Factors influencing big data decision-making quality. J. Bus. Res. 2016, 70, 338-345. [CrossRef]

84. Nguyen, A.; Gardner, L.A.; Sheridan, D. A Multi-Layered Taxonomy of Learning Analytics Applications. In Proceedings of the Pacific Asia Conference on Information Systems (PACIS), Langkawi Island, Malaysia, 16-20 July 2017; Volume 54. Available online: https:/ / aisel.aisnet.org/pacis2017/54 (accessed on 20 October 2021).

85. Nguyen, A.; Gardner, L.; Sheridan, D. Data Analytics in Higher Education: An Integrated View. J. Inf. Syst. Educ. 2020, $31,61-71$. Available online: http://jise.org/Volume31/n1/JISEv31n1p61.html (accessed on 20 October 2021).

86. Falakmasir, M.H.; Moaven, S.; Abolhassani, H.; Habibi, J. Business intelligence in e-learning: Case study on the Iran university of science and technology dataset. In Proceedings of the 2nd International Conference on Software Engineering and Data Mining, Chengdu, China, 23-25 June 2010; pp. 473-477. Available online: https://ieeexplore.iee.org/abstract/document/5542876 (accessed on 20 October 2021).

87. McPhillips, M. Trouble in Paradise? Barriers to Open Innovation in Regional Clusters in the Era of the 4th Industrial Revolution. J. Open Innov. Technol. Mark. Complex. 2020, 6, 84. [CrossRef]

88. Elhassan, I.; Klett, F. Bridging higher education and market dynamics in a business intelligence framework. In Proceedings of the 2015 International Conference on Developments of E-Systems Engineering, Dubai, United Arab Emirates, 12-15 December 2015; pp. 198-203.

89. Alkhalil, A.; Abdallah, M.A.E.; Alogali, A.; Aljaloud, A. Applying Big Data Analytics in Higher Education: A Systematic Mapping Study. Int. J. Inf. Commun. Technol. Educ. (IJICTE) 2021, 17, 29-51. [CrossRef]

90. Maroufkhani, P.; Wagner, R.; Wan Ismail, W.K.; Baroto, M.B.; Nourani, M. Big data analytics and firm performance: A systematic review. Information 2019, 10, 226. [CrossRef]

91. Inkinen, H.T.; Kianto, A.; Vanhala, M. Knowledge management practices and innovation performance in Finland. Balt. J. Manag. 2015, 10. [CrossRef]

92. Masa'deh, R.; Shannak, R.; Maqableh, M.; Tarhini, A. The impact of knowledge management on job performance in higher education: The case of the University of Jordan. J. Enterp. Inf. Manag. 2017, 30, 244-262. [CrossRef]

93. Grant, R.M. Toward a knowledge-based theory of the firm. Strateg. Manag. J. 1996, 17, 109-122. [CrossRef]

94. Mazdeh, M.M.; Hesamamiri, R. Knowledge management reliability and its impact on organizational performance: An empirical study. Program Electron. Libr. Inf. Syst. 2014, 48, 102-126.

95. Gold, A.H.; Malhotra, A.; Segars, A.H. Knowledge management: An organizational capabilities perspective. J. Manag. Inf. Syst. 2001, 18, 185-214. [CrossRef]

96. Darroch, J. Developing a measure of knowledge management behaviors and practices. J. Knowl. Manag. 2003, 7, 41-54. [CrossRef]

97. Mahamed Ismail, N.A.; Welch, C.; Xu, M. Towards a sustainable quality of university research: Knowledge sharing. Knowl. Manag. Res. Pract. 2015, 13, 168-177. [CrossRef]

98. Acharya, A.; Singh, S.K.; Pereira, V.; Singh, P. Big data, knowledge co-creation and decision making in fashion industry. Int. J. Inf. Manag. 2018, 42, 90-101. [CrossRef]

99. Santoro, G.; Fiano, F.; Bertoldi, B.; Ciampi, F. Big data for business management in the retail industry. Manag. Decis. 2019, 57, 1980-1992. [CrossRef]

100. Wang, S.; Wang, H. Big data for small and medium-sized enterprises (SME): A knowledge management model. J. Knowl. Manag. 2020, 24, 881-897. [CrossRef] 
101. Fernández-López, S.; Rodeiro-Pazos, D.; Calvo, N.; Rodríguez-Gulías, M.J. The effect of strategic knowledge management on the universities' performance: An empirical approach. J. Knowl. Manag. 2018, 22, 567-586. [CrossRef]

102. Van Ta, C.; Zyngier, S. Knowledge sharing barriers in Vietnamese higher education institutions (HEIS). Int. J. Knowl. Manag. 2018, 14, 51-70. [CrossRef]

103. Mohammed, A.A.; Hafeez-Baig, A.; Gururajan, R. An exploratory qualitative research to address processes that are utilised for managing knowledge: A case study in a Queensland Regional University. Int. J. High. Educ. Sustain. 2019, 2, $173-196$.

104. Joshi, H.; Chawla, D. How Knowledge Management Influences Performance? Evidences from Indian Manufacturing and Services Firms. Int. J. Knowl. Manag. 2019, 15, 56-77. [CrossRef]

105. Rehman, U.U.; Iqbal, A. Nexus of knowledge-oriented leadership, knowledge management, innovation and organizational performance in higher education. Bus. Process Manag. J. 2020, 26, 1731-1758. [CrossRef]

106. Ngah, R.; Tai, T.; Bontis, N. Knowledge management capabilities and organizational performance in roads and transport authority of Dubai: The mediating role of learning organization. Knowl. Process Manag. 2016, 23, 184-193. [CrossRef]

107. Shahzad, K.; Bajwa, S.U.; Siddiqi, A.F.I.; Ahmid, F.; Raza Sultani, A. Integrating knowledge management (KM) strategies and processes to enhance organizational creativity and performance: An empirical investigation. J. Model. Manag. 2016, 11, 154-179. [CrossRef]

108. Sahibzada, U.F.; Jianfeng, C.; Latif, K.F.; Sahibzada, H.F. Fueling knowledge management processes in Chinese higher education institutes (HEIs): The neglected mediating role of knowledge worker satisfaction. J. Enterp. Inf. Manag. 2020, 33, 1395-1417. [CrossRef]

109. Jain, N.; Gupta, V. The impact of knowledge management system on student performance: A case study of the University of Delhi. VINE J. Inf. Knowl. Manag. Syst. 2019, 49, 115-135. [CrossRef]

110. Lee, V.H.; Leong, L.Y.; Hew, T.S.; Ooi, K.B. Knowledge management: A key determinant in advancing technological innovation? J. Knowl. Manag. 2013, 17, 848-872. [CrossRef]

111. Ramjeawon, P.V.; Rowley, J. Knowledge management in higher education institutions: Enablers and barriers in Mauritius. Learn. Organ. 2017, 24, 366-377. [CrossRef]

112. Ataseven, C.; Prajogo, D.; Nair, A. ISO 9000 internalization and organizational commitment-implications for process improvement and operational performance. IEEE Trans. Eng. Manag. 2014, 61, 5-17. [CrossRef]

113. Kline, R.B. Convergence of structural equation modeling and multilevel modeling. In The SAGE Handbook of Innovation in Social Research Methods; SAGE Publications: Thousand Oaks, CA, USA, 2011.

114. Warheit, G.J.; Buhl, J.M.; Bell, R.A. A critique of social indicators analysis and key informants surveys as needs assessment methods. Eval. Program Plan. 1978, 1, 239-247. [CrossRef]

115. Bagozzi, R.P.; Yi, Y.; Phillips, L.W. Assessing construct validity in organizational research. Adm. Sci. Q. 1991, 36, 421-458. Available online: https://www.jstor.org/stable/2393203 (accessed on 20 October 2021). [CrossRef]

116. Ji-fan Ren, S.; Fosso Wamba, S.; Akter, S.; Dubey, R.; Childe, S.J. Modelling quality dynamics, business value and firm performance in a big data analytics environment. Int. J. Prod. Res. 2016, 55, 5011-5026. [CrossRef]

117. Chión, S.; Charles, C. Analítica de Datos Para la Modelación Estructural; Pearson Educación: London, UK, 2016.

118. Kline, R.B. Principles and Practice of Structural Equation Modeling; Guilford Publications: New York, NY, USA, 2015.

119. Nunnally, J. Psychometric Methods; McGraw-Hill: New York, NY, USA, 1978.

120. Fornell, C.; Larcker, D.F. Evaluating structural equation models with unobservable variables and measurement error. J. Mark. Res. 1981, 18, 39-50. [CrossRef]

121. Ping, R. On assuring valid measures for theoretical models using survey data. J. Bus. Res. 2004, 57, 125-141. [CrossRef]

122. Amalia, F.A.; Sosianika, A.; Suhartanto, D. Indonesian Millennials' Halal food purchasing: Merely a habit? Br. Food J. 2020, 122, 1185-1198. [CrossRef]

123. Anderson, J.C.; Gerbing, D.W. Structural equation modeling in practice: A review and recommended two-step approach. Psychol. Bull. 1988, 103, 411. [CrossRef]

124. Byrne, B.M. Structural Equation Modeling with AMOS: Basic Concepts-Applications and Programming; Routledge: Mahwah, NJ, USA, 2001.

125. Hair, J.; Black, W.; Babin, B.; Anderson, R. Multivariate Data Analysis, 7th ed.; Prentice Hall: Mexico City, Mexico, 2010.

126. Woo, E.; Kim, Y.G. Consumer attitudes and buying behavior for green food products: From the aspect of green perceived value (GPV). Br. Food J. 2019, 121, 320-332. [CrossRef]

127. Sobel, M.E. Some new results on indirect effects and their standard errors in covariance structure models. Sociol. Methodol. 1986, 16, 159-186. Available online: https:/ / www.jstor.org/stable/270922 (accessed on 20 October 2021). [CrossRef]

128. Kandil, A.M.N.A.; Ragheb, M.A.; Ragab, A.A.; Farouk, M. Examining the effect of TOE model on cloud computing adoption in Egypt. Bus. Manag. Rev. 2018, 9, 113-123.

129. Ghobakhloo, M.; Arias-Aranda, D.; Benitez-Amado, J. Adoption of e-commerce applications in SMEs. Ind. Manag. Data Syst. 2011, 111, 1238-1269. [CrossRef]

130. Rumanti, A.A.; Rizana, A.F.; Ramadhan, F.; Reynaldo, R. The Impact of Open Innovation Preparation on Organizational Performance: A Systematic Literature Review. IEEE Access 2021, 9. [CrossRef]

131. Jayabalan, J.; Dorasamy, M.; Raman, M. Reshaping Higher Educational Institutions through Frugal Open Innovation. J. Open Innov. Technol. Mark. Complex. 2021, 7, 145. [CrossRef] 
132. Lassen, A.H.; Laugen, B.T. Open innovation: On the influence of internal and external collaboration on degree of newness. Bus. Process Manag. J. 2017, 23. [CrossRef]

133. Low, C.; Chen, Y.; Wu, M. Understanding the determinants of cloud computing adoption. Ind. Manag. Data Syst. 2011, 111, 1006-1023. [CrossRef]

134. Ali, S.; Poulova, P.; Yasmin, F.; Danish, M.; Akhtar, W.; Usama Javed, H.M. How Big Data Analytics Boosts Organizational Performance: The Mediating Role of the Sustainable Product Development. J. Open Innov. Technol. Mark. Complex. 2020, 6, 190. [CrossRef]

135. Cherian, J.; Jacob, J.; Qureshi, R.; Gaikar, V. Relationship between entry grades and attrition trends in the context of higher education: Implication for open innovation of education policy. J. Open Innov. Technol. Mark. Complex. 2020, 6, 199. [CrossRef]

136. Del Vecchio, P.; Mele, G.; Ndou, V.; Secundo, G. Open innovation and social big data for sustainability: Evidence from the tourism industry. Sustainability 2018, 10, 3215. [CrossRef]

137. Ahmad, N.; Lodhi, M.S.; Zaman, K.; Naseem, I. Knowledge management: A gateway for organizational performance. J. Knowl. Econom. 2015, 8, 859-876. [CrossRef]

138. Tejedor, S.; Cervi, L.; Pérez-Escoda, A.; Tusa, F.; Parola, A. Higher education response in the time of coronavirus: Perceptions of teachers and students, and open innovation. J. Open Innov. Technol. Mark. Complex. 2021, 7, 43. [CrossRef]

139. Huggins, R.; Prokop, D.; Thompson, P. Universities and open innovation: The determinants of network centrality. J. Technol. Transf. 2020, 45, 718-757. [CrossRef]

140. Pereira, L.; Fernandes, A.; Sempiterno, M.; Dias, Á.; Lopes da Costa, R.; António, N. Knowledge management maturity contributes to project-based companies in an open innovation era. J. Open Innov. Technol. Mark. Complex. 2021, 7, 126. [CrossRef]

141. Vélez-Rolón, A.M.; Méndez-Pinzón, M.; Acevedo, O.L. Open Innovation Community for University-Industry Knowledge Transfer: A Colombian Case. J. Open Innov. Technol. Mark. Complex. 2020, 6, 181. [CrossRef]

142. Chen, Y.W.; Shae, Z.Y. Blockchain for pre-clinical and clinical platform with big data. In Application of Omics, Ai and Blockchain in Bioinformatics Research; World Scientific: Hackensack, NJ, USA, 2020; pp. 29-46. 